移動ロボットが複数台になった場合や，移動ロボットにマニピュレータが搭載された場合，動作検証に時閒が かかるだけでなく，どの上うな問題が発生寸るか予測がつかない場合がある。そこで，本研究では，移動口ボッ トの動作プログラムの動作検証を行うことができるシミュレータを開発した。このシミュレータの特徴は，実機 上で動作させるプログラムと同じプログラムで，シミュレータ内のロボットを 2 台まで動作させることができる 点である

Key Words: Simulator, Motion Programming, Mobile Robots

1P1-G10 磁石振り子を用いた管内移動ロボットの研究

Development of In-pipe Robot with Pendurum-magnet

○小林 進吾(電気通信大学)，田口 幹(電気通信大学共同研究センター)

OShingo Kobayashi(University of Electro-Communications),

Kan Taguchi(University of Electro-Communications Cooperative Research Center 配管を内部より検査する管内移動ロボットの要求は多い。本研究公では磁石振り子を用いた壁面吸着移動ロボ ットを開発している。本報では，この機構を管内移動ロボットに適用したので報告する。試作したロボットは内 径 $100 \mathrm{~mm}$ の鋼管内を水平，垂直方向に移動できるだけでなく，ステアリングすることで $\mathrm{T}$ 字管を自由に曲がるこ とができ，管径の多少の変化やプラグ等の突起物の回避に柔軟な対忘をすることができる。

Key Words: Vehicle in Pipe, Pendurum with Magnet

38. 新しいロボットメカニズムの開発

6 月 8 日（土） 12:30 14:30 H 列

1P1-H01＼cjkstart地中埋設管測量機能を持った管内走行検査ロボット

○大野学 (日本工大)，㾇野聡明 (日本工大)，加藤重雄 (日本工大)，松田信一(富士写真光機)

Development of an In-pipe Mobile Inspection Robot with a Position Surveying System

OManabu ONO(Nippon Institute of Technology), Toshiaki HAMANO(Nippon Institute of Technology),

Shigeo KATO(Nippon Institute of Technology), Shinichi MATSUDA(Fuji Photo Optical Co., Ltd.)

配管の傷や腐食が原因となり，様々な事故が発生している。配管の内部からの検査は，事故の予防に有効であ り，検査すると同時に，配管の埋設位置を特定できれば，多くの作業が軽減されるであるう。今回，地中埋設管 測量機能を持った検榃ロボットを開発した。家庭に配管される内待 $44 \mathrm{~mm}$ ，距離 $20 \mathrm{~m}$ の配管を，2 個のロータリエ ンコーダより構成される測量装置を產引した状熊で, 13 分 43 秒で走行した。また, CCD力メラで管内の傷や、ゴ ミ在映像で確認寸ることができ，傷の場所や配管の埋設位置の特定ができた。

Key Words: In-pipe, Inspection, Bellows, Pneumatic, Position-surveying

1P1-H02 不整地移動機構の開発

（第 1 報：試作機製作および動作検証）

Development of Mobile System using Leg-type Crawlers for Rough Terrain

(1st Report ; Examination of Mobility using Prototype System)

Sho Yokota(Hosei University), Kawabata Kuniaki(RIKEN), Hisato Kobayashi(Hosei University)

本研究は，クローラと脚を組み合わせたクローラ脚を用いた新しい移動機構を開発を目的としている。提案导 る移動機構は，不整地走破能力の高いクローラの動作と脚の動作を組み合わせることで，従来のクローラだけの 移動ロボットより，さらに留い不整地走破性を発揮する。また，システ構成に柔軟性を持たせるため，クロー ラ脚をモジュール化しており，故障時などにもそのモジュールを切り離すことで走行が継続可能となっている。 本稿では，クローラ脚を用いたシステムの試作を行い，試作機による動作実験の結果について報告をする。

Key Words: Mobile Robot, Leg-type crawler, Rough terain, Mechanism

1P1-H03 メカニカルシステムのための出力分配機構の開発

\title{
Development of Output Distributing Mechanism for Mechanical Systems.
}

○原口 林太郎(京都大学)，大須賀 公一 (京都大学)

R.Haraguchi (Kyoto Univ.), K.Osuka(Kyoto Univ.)

現在作業ロボットに十分余裕のある出力をもたせるのは困難でありここのために能力に限界があることも少な くない. そこで, 本研究ではメカニカルシステムにおいて余剩出力が存在寸る場合があることに注目し, この出力 を利用して高出力を達成するための機構として出力分配機構の提案を行う。この機構は, 多入出力を持つシステム の各々の入力に扔ける余㮃出力を他の出力へと分配することを可能とするものであり, 2 入力 2 出力の場合として 差動歯車を用いた複合差動㐘車機構についての解説および式作機による検諩の結果の報告を行う。

Key Words: mechanism, output, actuator

1P1-H04 空気圧アクチュエータを用いたマスタスレーブシステムの開発

小林宏 (東理大，科技団さきがけ研究 21 )，O真鍋健太郎 (東理大)，宮島隆至(東理大)

Development on Master-Slave Arm System by Pneumatic Actuator.

H. Kobayashi(Science Univ. of Tokyo \& PRESTO, JST), OK. Manabe(Science Univ. of Tokyo), T. miyajima(Science Univ. of Tokyo )

差動機構を用いた装着型マスタと，空気圧アクチュェータを用いて駆動するスレーブアームからなるマスタス レーブシステムについて発表する。マスタは，角度操作や，装着者への反力の発生に関して，小型軽量な差動機 構を用い，人間に装着して肩から前腕までの動きをスレーブ側に送る。スレーブは, 軽量, 大出力な空気厌アク チュエータを用い，人閒の肩から前腕までを模したアームを駆動し，人間の上らな滑らかな動きを実現する。

Key Words: Master-Slave System, Pneumatic Actuator, Bilateral control, Robot Arm, Differential Mechanism

1P1-H05 壁面吸着型全方向移動ロボット

The omni directional vehicle moved on the wall

○鶴清 (東京工業大学)，広瀬茂男 (東京工業大学)

K. Tsuru(T. I. Tech), S.Hirose(T. I. Tech)

壁面に吸着して移動寸るロボットは，壁面の亀裂，損傷および錆などを発見する目的から現在開発が進められ ている。しかし，壁面の表面にわずかの凹ロがあると吸着機構に悪影響を及洼し移動が困難になる。本開発はこ のような課題を解決寸るために, 強力な力で接着している永久磁不をゼロの力で剥離する機構であるIBマグネッ トを，、ボットの両足に用いることを特徵にした。移動方法は，ひとつ目の足を壁面に固定し，それを支点にし て他の足を円を描くように移動して壁面に固定して支点と寸る.そしてひとつ目の足を壁面から剥離して円移動 して固定する。この動作を繰り返すことで壁面の上下左右の全方向への移動を叮能にする。さらに，小型・軽量 化も達成できる.

Key Words: magnet, omni 